\title{
Retinoblastoma pT1 TNM Finding v7
}

National Cancer Institute

\section{Source}

National Cancer Institute. Retinoblastoma pT1 TNM Finding v7. NCI Thesaurus. Code C88729.

Retinoblastoma with tumor confined to eye with no optic nerve or choroidal invasion. (from AJCC 7th Ed.) 